依 頼 論 文 企画論文 : 認知症高齢者に対する補綴歯科治療の考え方

\title{
認知症高齢者に対する補経歯科治療の考え方
}

服部 佳功

\section{What to think through about prosthodontic treatment for elderly people with dementia}

\author{
Yoshinori Hattori, DDS, PhD
}

認知症は年齢依存性のきわめて高い病態である。本 邦における認知症患者数の著しい増大は, 世界最高水 準を達成した長寿のいわば必然の帰結であり，われわ れ歯科医師が認知症高齢者の歯科治療を行うことは, 補綴治療を含め，もはや特別なことではなくなった。 認知症はまた進行性の病態でもある。認知症が進行す れば補綴治療の必要性への理解が低まり, 新義歯への 適応困難や義歯の使用不能, 誤飲などの危険も高まる. その一方で，栄養の充足は認知機能の維持に重要であ り，認知症であることを理由に補緅治療を回避するこ とは必ずしも適切とは限らない。

認知症の病期に応じた補綴治療の必要性はこのよう に明らかだが，現状，エビデンスに基づいて治療方針 の立案が可能な状況からはほど遠い. 加えて認知症進 行に伴う意思疎通の困難は医療行為への同意の著しい 障害である。生命との直接的関連にそしくしばしば緊 急性を欠く補綴治療において，どのような意思決定プ ロセスが適切であるかの検討はまったくなされていな いに等しい.

上述の問題を重く捉えた本誌編集委員会は，「認知症 高齢者に対する補綴歯科治療の考え方」と題した一連 の解説記事を企画した。記事は以下の 4 部からなる.

第 1 部は, 認知症に関する適切な理解を促すもので, 順天堂大学で老人精神医学をご専攻の新井平伊先生, 柴田展人先生にごく平易な解説をお願いした。しかし
その内容は，認知症の概論に止まらず，認知症患者に おける口腔ケアや補綴治療の意義や重要性, 認知症に 随伴することが稀ではない口腔異常感症にも及び，す こぶる有用な解説となっている.

第 2 部は, 東京都健康長寿医療センターの平野浩彦 先生による認知症高齢者における歯科治療立案プロセ スの解説である。このプロセスの何が問題で，どのよ うな困難があり，いかなる対処が可能かが詳述された 記事には，問診の方法などへの言及までが含まれ，き わめて実践的な内容である.

第 3 部は, 徳島大学, 地域医療福祉学の白山靖彦先 生に, 社会福祉学の視点からみた認知症高齢者におけ る医療行為の同意など，意思決定プロセスの問題点や 解決に向けた取り組みをご紹介いただいた。介護福祉 や行政を含めた多職種に加えて親族や友人・知人まで もが参加する合意形成の取り組みは，多様な立場の当 事者が責任を相互補完することで認知症患者の権利擁 護を図ろうとするもので，おおいに示唆に富む。

第 4 部は, 編集委員である東北大学の服部佳功が, 現状入手可能な文献に基づいて，この領域の問題点や 現況を総説的に解説した。

この企画を機に，補綴歯科領域で認知症高齢者への 対応に関して談論が風発し, ガイドライン作成など意 思決定プロセスの定式化に向けての道筋が形成されん ことを期待する. 